\title{
The Judgment Of The Criminal Action Of Narcotics In Islamic Law Perspective And Human Rights Protection
}

\author{
Eka Santosa ${ }^{1}$
}

\begin{abstract}
The formulations of the problems in this research are: What is the basis for the judge's consideration in making a decision regarding the crime of narcotics abuse in the Pekalongan District Court? And how is the court's decision regarding narcotics crime based on the decision of the Pekalongan District Court from the perspective of Islamic law and protection of human rights human?

The research carried out in this thesis is normative legal research, namely research on problems by looking at the prevailing regulations. The approach method used is normative legal research which is literature research, namely research on secondary data.

The results of the research were as follows: Whereas narcotics crime is a crime, for this reason, a set of laws that regulate criminal sanctions for narcotics abuse is needed, namely: Law No. 35 of 2009 concerning Narcotics. The purpose of making Law No. 35 of 2009 concerning Narcotics is to prevent the occurrence of narcotics abuse and to eradicate illicit narcotics trafficking. The formulation of offenses in the aforementioned law focuses on the abuse and distribution of narcotics starting from cultivation, production, distribution, traffic to the users, not on assets obtained from criminal acts. The basis for consideration of judges in making decisions are: Judgments of a judicial nature, considerations of a non-judicial nature, and things that are burdensome and alleviate the crime. Judges must not only be based on statutory regulations, but must pay attention to the general feelings and opinions of the community.

Keywords: Narcotics Crime, Islamic Law, Human Rights
\end{abstract}

\section{Introduction}

The Republic of Indonesia is a state based on law, as stated in the 1945 Constitution. This has the consequence that the State, including the government and other state institutions, must be accountable for any action in the implementation of any action, therefore every action must be based on law. ${ }^{2}$

Law enforcement or in its popular language, often referred to as law enforcement, is the spearhead so that the creation of a good legal order in a law society that is not enforced is the same as no law. Law enforcement is a series of activities in the context of efforts to implement applicable legal provisions, both in the form of repression and prevention, covering all both technical and

\footnotetext{
${ }^{1}$ Indonesian National Police

2 Ali Mansyur, 2007, Aneka Persoalan Hukum, Masalah Perjanjian, Konsumen dan Pembaharuan Hukum, UNISSULA Press, Semarang, p. 131.
} 
administrative activities carried out by law enforcement officials, so as to create a safe, peaceful and orderly atmosphere for the sake of strengthening legal certainty. in society. ${ }^{3}$

In criminal law, the term criminal offense is a translation from the Dutch language Strafbaarfeit which is the official term in Wetboek Van Starfrecht which has been translated into Indonesian with the Criminal Code (KUHP), which is still valid in Indonesia today. ${ }^{4}$

Systematically, the Criminal Code (KUHP) divides criminal acts into two parts, namely: 5

a. Crime

b. Offense.

Indonesia as a country with a large population is a potential target for international syndicates. The government considers the narcotics problem as a national concern.

The impact of narcotics when misused will bring destruction to the individual using it, society and even the state. Especially if the victims of abuse are the younger generation.

Data as released by the National Narcotics Agency shows the tendency for narcotics crimes committed by student and student age actors is as follows:

Table 1

Narcotics Case Data 2001 - 2008 Based on Age

\begin{tabular}{cccccccccccc}
\hline No. & Age & \multicolumn{1}{c}{ Years } & \multicolumn{1}{c}{ YEAR } & \multicolumn{1}{c}{ total } & Average \\
& \cline { 3 - 11 } & 2001 & 2002 & 2003 & 2004 & 2005 & 2006 & 2007 & 2008 & Total & per year \\
\hline 1 & $<16$ & 25 & 23 & 87 & 71 & 127 & 175 & 110 & 133 & 751 & 150 \\
\hline 2 & $16-19$ & 501 & 494 & 500 & 763 & 1,668 & 2,447 & 2,617 & 2,001 & 10,991 & 2,198 \\
\hline 3 & $20-24$ & 1,428 & 1,755 & 2,457 & 2,879 & 5,503 & 8,383 & 8,275 & 6,441 & 37,121 & 7,424 \\
\hline 4 & $25-29$ & 1,366 & 1,386 & 2,417 & 2,888 & 6,442 & 8,105 & 9,278 & 10,126 & 42,008 & 8,402 \\
\hline 5 & $>29$ & 1,604 & 1,652 & 4,256 & 4,722 & 9,040 & 12,525 & 15,993 & 25,993 & 75,681 & 15,136 \\
\hline & total & 4,924 & 5,310 & 9,717 & 11,323 & 22,780 & 31,635 & 36,169 & 44,694 & 166,552 & 33,310 \\
\hline
\end{tabular}

Source: BNN data

Seeing the data above is very sad because from year to year the circulation of narcotics in Indonesia has increased quite significantly, the danger of narcotics abuse is very bad for all parties. For the user it will result in apparent pleasure and dependence. For the younger generation, of course this will be detrimental to themselves and to the nation.

To anticipate the widespread abuse of narcotics and the eradication of illicit narcotics trafficking, the government issued Law No. 39 of 2009 following the rules. Law Number 35 of 2009 concerning Narcotics regulates criminal provisions. Criminal acts in the field of psychotropics as regulated in this law are crimes. ${ }^{6}$

\footnotetext{
3 Soejono Sukanto, Penegakan Hukum dan Kesadaran Hukum, Papers On National Law Semintar, 4th, Jakarta, 1979, p. 2

${ }^{4}$ Mardani, 2008, Penyalahgunaan Narkoba, Dalam Perspektif Hukum Islam dan hukum Pidana Nasional, PT. Raja Grafindo Persada, p. 59

${ }^{5}$ Moelyanto, 1985, KUHP, PT. Bina Aksara, Jakarta, p. 51

6 Siswanto Sunarso, 2004, Penegakan Hukum Psikotropika dalam Kajian Sosiologi Hukum, PT RajaGrafindo Persada, Jakarta, page 2.
} 
Based on observations of the court's performance in processing criminals in court proceedings, it is known that the judge's verdict on narcotics crime has not been as severe as the provisions in the law in the conviction. The law stipulates the maximum sentence, but some other judges never apply the maximum sentence. Even though Law No. 35 of 2000 concerning Narcotics strictly regulates criminal sanctions including capital punishment. ${ }^{7}$

In Law No. 35 of 2009 states that the notion of Narcotics is a substance or drug derived from plants or non-plants, both synthetic and semisynthetic, which can cause a decrease or change in consciousness, loss of taste, reduce to eliminate pain, and can cause dependence, which are differentiated into groups. -classes as attached in this Law. ${ }^{8}$

Capital punishment is a radical effort to eliminate people who cannot be repaired, and with this capital punishment the obligation to keep them in prisons is so large. ${ }^{9}$

However, the execution of the death penalty violates Human Rights (HAM), namely the right to life. This right is contained in Article 28A of the 1945 Constitution which states "everyone has the right to live and has the right to defend his life and life". So they consider that the right to life is the most basic right and cannot be reduced under any circumstances.

It is viewed through a humanitarian philosophical approach that the death penalty is very appropriate to be imposed on narcotics abusers, especially against their networks and traffickers. Therefore, the consequences of these acts are very heavy and the crimes are serious, which in the end can destroy most of the young generation of a nation. ${ }^{10}$

Narcotics crime is a special crime. As with special crimes, judges are allowed to sentence two main crimes at the same time, in general a corporal punishment and a fine. Corporal punishment is in the form of death penalty, life imprisonment, or imprisonment. The goal is that the punishment is burdensome to the perpetrator so that the crime can be handled in the community, because the narcotics crime is very dangerous to the interests of the nation and the state. ${ }^{11}$

Law No. 35 of 2009 concerning Narcotics gives authority to judges to decide at a narcotics addiction rehabilitation center if the perpetrator of the crime is only an addict or suffering from a dependency syndrome. Rehabilitation is intended to restore and / or develop physical, mental and social abilities. But the fact is that judges rarely use this authority. Not infrequently judges decide criminal cases of narcotics who are addicts and who suffer from a dependency syndrome with imprisonment / imprisonment plus fines which if the fines are not paid will be replaced by imprisonment in lieu of fines.

In this paper, law enforcers are limited to judges. A law enforcer, like other members of society, usually has several positions and roles at once. Thus it is not

\footnotetext{
${ }^{7}$ Article 59 of Law No. 5 of 1997 concerning Psychotropics

${ }^{8}$ Article 1 number 1 Law No. 35 of 2009 concerning Narcotics

${ }^{9}$ Andi Hamzah, et al, 1984, Pidana Mati di Indonesia di Masa Lalu, Kini dan di Masa Depan. Ghalia Indonesia, Jakarta, p. 27.

10 Moh. Taufik Makaro et al Tindak Pidana Narkotika, Ghalia Indonesia, Jakarta, 2005, p. 47.

11 Gatot Supramono, Hukum Narkoba Indonesia, Djambat, Jakarta, 2004, p. 9
} 
impossible that conflicts arise between various positions and roles (status conflict and conflict of roles). ${ }^{12}$

The issue of role is considered important, because discussion of law enforcement is actually more focused on discretion. The proper role of certain law enforcement circles has been formulated in Law No. 48 of 2009 concerning Judicial Power. ${ }^{13}$

The ideal role can be seen in Article 1 of Law Number 48 Year 2009 which contains: Judicial power is the power of an independent State to administer justice to enforce law and justice based on Pancasila and the 1945 Constitution of the Republic of Indonesia, for the sake of the implementation of the State. Law of the Republic of Indonesia.

According to the Criminal Procedure Code, judges are state judicial officials who are authorized by law to judge. The judge in the trial process is the leader. This position gives the right to regulate the proceedings of the trial and to take action when there is disorder in the trial. The judge who is the leader in the trial process in an effort to apply the law for justice must be aware of his responsibility so that if he acts and acts it is not only about making a decision, but also that all his actions are always directed towards realizing justice based on Almighty God.

Based on the description that has been stated, the author is interested in examining the judge's decision entitled Analysis of Court Decisions Against Narcotics Crime from the Perspective of Islamic Law and Protection of Human Rights.

\section{Research Methodology}

This type of research is normative juridical research, namely research on problems by looking at the prevailing regulations. Types and sources of data used are primary data and secondary data. Primary data were obtained through interviews, while secondary data consisting of primary, secondary and tertiary legal materials used literature studies. The data obtained from the research results in the form of primary data and secondary data are then collected and arranged regularly for analysis. In writing this research, the writer uses qualitative data analysis, which is a method of research that produces descriptive analysis data, namely those stated by the respondent in writing or orally as well as behavior that is actually researched and studied as a whole.

\section{Research Results And Discussion}

\subsection{Basic Consideration of Judges in Making Decisions on the Crime of Narcotics Abuse in Pekalongan District Court}

There are several things that need to be considered in passing a sentence. This can be seen in Article 55 paragraph (1) of the 2006 Criminal Code Bill, namely:

\footnotetext{
12 Ibid., p. 21

13 Ibid., p. 23
} 
a. Crime maker error;

b. The motive and purpose of committing a criminal act;

c. The inner attitude of the criminal;

d. Whether the crime was committed in a planned manner;

e. How to commit a criminal act;

f. Attitudes and actions of the maker after committing a criminal act;

g. Life history and social and economic conditions of the criminal;

h. Effects of crime on the future of the criminal offender;

i. The influence of the crime on the victim or the victim's family;

j. Forgiveness of the victim and / or their family and / or;

k. Public view of the criminal act committed.

One of the judges' considerations in imposing a sentence is things that are burdensome and things that lighten the defendant. In the trial, the judge before imposing a sentence on the defendant to commit the seriousness or lightness of the sentence to be imposed must base himself on seeing and assessing the circumstances contained in the defendant, whether the defendant has been convicted before or not, whether the defendant has been courteous or not in the trial, acknowledges and regret his actions or not. Consideration is also made on what and the role and position of the defendant as well as the amount of evidence presented at trial that affects the severity or lightness of the sentence imposed on a defendant.

\subsection{Amar Court Decision Regarding Narcotics Crime Based on Pekalongan District Court Decision Viewed From Perspective of Islamic Law and Protection of Human Rights}

a. Judging from Islamic Law Perspective

From the description that the author has explained in the previous chapter, it is clear that there is no difference in the imposition of sentences carried out by judges who aim to create security and order for the people, namely through various means and Islam prohibits its people from committing actions that destroy human faith and morals. as well as disturbing security and public order

According to Islam, the judge cannot determine a sentence because he saw the perpetrator drinking alcoholic drinks or was drunk and the perpetrator admitted drinking liquor as long as the incident did not occur in court.

b. In terms of human rights

With the promulgation of Law No. 35 of 2009 on Narcotics, it actually does not answer the problem of Narcotics addicts. In Law 35 of 2009 that Narcotics addicts are people who use or abuse Narcotics and are in a state of dependence on Narcotics, both physically and psychologically. However, it is difficult for addicts or Narcotics Abusers to also be placed in a difficult position. As part of Victimless Crime, addicts or abusers should not be placed as a crime, unless the group is proven to be part of the Narcotics distribution network.

However, the national criminal law policy still requires a political punishment in the form of imprisonment. Some of the threats that can be traced are for example: Article 127, Article 128, and Article 134. There may also be other 
provisions in the Narcotics Law. However, there is something interesting, the Supreme Court of the Republic of Indonesia issued SEMA No. 04/2010 concerning the Placement of Abuse, Abuse Victims and Narcotics Addicts into Medical Rehabilitation and Social Rehabilitation Institutions. SEMA is at least one of the harm reduction efforts that have been responded positively by the perpetrators of the judicial power. SEMA was issued in response to Article 103 paragraph (1) of Law 35/2009 which states: A judge examining a Narcotics Addict case can: (a) decide to order the person concerned to undergo treatment and / or treatment through rehabilitation if the Narcotics Addict is found guilty of committing a Narcotics crime; or (b) stipulates to order the person concerned to undergo treatment and / or treatment through rehabilitation if the Narcotics Addict is not proven guilty of committing a Narcotics crime.

However, this SEMA does not answer the problem of the possibility of arrest and detention carried out by investigators, which can at least be expected to occur because Law 35 of 2009 opens up opportunities for this possibility, especially with the threat of large penalties. We can see several articles that in our opinion there is a change for the better in the resolution of the Narcotics case. Apart from the aforementioned statutory provisions there is still hope for narcotics addicts with the Pekalongan District Court's decision which sentenced a narcotics dealer to imprisonment. In the Pekalongan District Court itself, in verifying addicts and dealers based on objective decisions, in this case the judge did not consider the difference between addicts and dealers. In his decision, the judge should consider that many narcotic prisoners who are from a health perspective are sick people who need health therapy. Furthermore, prison is not the right place for drug addicts who experience addiction.

Consideration of the verdict for addicts caught in control of narcotics for the needs of addicts who experience dependence so that they are obliged to undergo rehabilitation and are counted as a period of detention. On the basis of all that, the Panel of Judges dared to make a breakthrough by using Article 47 of Law number 22 of 1997 concerning Narcotics which gives the judge the authority to sentence a narcotic addict to undergo rehabilitation. Authority as affirmed by the Circular Letter of the Supreme Court of the Republic of Indonesia (SEMA RI) No. 7 of 2009. In its verdict, the Panel of Judges not only handed down a crime but also ordered the defendant to undergo rehabilitation

The consideration of the Panel of Judges that views addicts as sick people who need health therapy and prisons are not the right place for addicts is a consideration that deserves to be appreciated and considered by all judges in Indonesia. With this consideration, the panel of judges will instead support the narcotics countermeasures program in this country. Just imprisoning addicts, without giving them the opportunity for rehabilitation is tantamount to neglecting human rights. Now, it's the turn for the policy, especially the District Attorney, to immediately implement this decision. By immediately implementing this decision, the Prosecutor means supporting efforts to heal and restore the dignity of addicts as human beings.

The judge's decision in looking at the addiction problem which is closely related to rehabilitation needs to be responded very positively and supported. The readiness of rehabilitation centers and institutions is of course important now in 
accepting narcotics addicts so that they comply with proper and proper health standards.

In terms of human rights if we refer to Law no. 35 of 2009 that the criminal provisions against narcotics abuse in applying the criminal provisions are also immediately followed by the obligation to pay attention to the provisions of the article regarding the rehabilitation of narcotics addicts contained in the provisions of paragraph (2).

Although it is still free for judges to impose a sentence in their decision in handling cases of narcotics addicts (based on the judge's conviction) in terms of imposing sanctions. Thing

This can be proven by seeing and also understanding the criminal provisions against narcotics abuse offenders for themselves. Likewise with the case mentioned above, from the evidence and witnesses that the defendant was a dealer and not an addict, but the judge considered that the defendant was still a student or student who still had a future that needed to be nurtured and guided.

\section{Clossing}

\subsection{Conclusion}

The purpose of making Narcotics is to prevent the abuse of narcotics and to eradicate illicit narcotics trafficking. Therefore, all the formulations of offenses in the two laws above are focused on the abuse and distribution of narcotics starting from the cultivation, production, distribution, traffic of circulation to the users, not on assets obtained from criminal acts. The sanctions and convictions under these two laws vary. The basis for the judges' considerations in making a decision on the crime of narcotics abuse are: Judicial considerations, Non-judicial considerations.

\subsection{Suggestions}

Based on the above conclusions, the following suggestions are made: Judges in deciding cases of narcotics crime still use formal legal principles, this can be seen in the imprisonment for every drug dealer and addict with the same sentence, namely imprisonment, even though narcotics addicts have a different need for a rehabilitation decision as a user. narcotics. Judges in imposing criminal decisions on narcotics, especially narcotics addicts, are not based solely on formal law but rather on legal benefits, namely medical rehabilitation; Judges can impose capital punishment on the accused, producers and traffickers of narcotics as regulated in Article 113 Paragraph 2 and Article 114 Paragraph 2 of Law No. Human Rights and Human Basic Freedoms (Right to Life) as referred to in Article 9 of Law No. 39 of 1999 concerning Human Rights.

\section{Bibliography}

[1] Ali Mansyur, 2007, Aneka Persoalan Hukum, Masalah Perjanjian, Konsumen dan Pembaharuan Hukum, UNISSULA Press, Semarang. 
[2] Soejono Sukanto, Penegakan Hukum dan Kesadaran Hukum, Papers On National Law Semintar, 4th, Jakarta, 1979.

[3] Mardani, Penyalahgunaan Narkoba, Dalam Perspektif Hukum Islam dan hukum Pidana Nasional, PT. Raja Grafindo Persada, 2008.

[4] Moelyanto, KUHP, PT. Bina Aksara, Jakarta, 1985.

[5] Siswanto Sunarso, Penegakan Hukum Psikotropika dalam Kajian Sosiologi Hukum, PT RajaGrafindo Persada, Jakarta, 2004.

[6] Andi Hamzah, et al, Pidana Mati di Indonesia di Masa Lalu, Kini dan di Masa Depan. Ghalia Indonesia, Jakarta, 1984.

[7] Moh. Taufik Makaro et al Tindak Pidana Narkotika, Ghalia Indonesia, Jakarta, 2005.

[8] Gatot Supramono, Hukum Narkoba Indonesia, Djambat, Jakarta, 2004.

[9] 1945 Constitution.

[10] Criminal Procedure Code.

[11] Law Number 4 of 2004 concerning Judicial Power.

[12] Law Number 22 Year 1997 Concerning Narcotics.

[13] Law Number 5 of 1997 concerning Psychotropics.

[14] Law Number 35 of 2009 concerning Narcotics

[15] Law Number 48 of 2009 concerning Judicial Power

[16] Law Number 39 of 1999 concerning Human Rights 